\title{
Wind Characteristics Analysis for Selected Site in Algeria
}

\author{
Maouedj Rachid \\ Unity of Research in \\ Renewable Energies in \\ Saharan Medium. \\ Adrar. Algeria.
}

\author{
Diaf Said \\ Centre of Renewable Energies \\ Development, B.P 62, \\ Bouzareah, Algiers, Algeria I
}

\author{
Benyoucef Boumediene \\ Unity of Research in Materials \\ and Renewable Energies, \\ University of Tlemcen, Algeria
}

\begin{abstract}
The wind characteristics of four locations in Algeria (Algiers, Oran, Adrar and Ghardaia) have been assessed. The data were collected over a period of 13 year. The wind speed characteristics and wind power potential of each station have been determined using Weibull distribution.

The annual average wind speed for the selected sites ranged from $3.81 \mathrm{~m} / \mathrm{s}$ to $6.38 \mathrm{~m} / \mathrm{s}$ and a mean wind power density from $97.26 \mathrm{w} / \mathrm{m}^{2}$ to $270.17 \mathrm{w} / \mathrm{m}^{2}$ at standard height of $10 \mathrm{~m}$. The wind data at heights $30 \mathrm{~m}$ and $50 \mathrm{~m}$ were obtained by extrapolation of the $10 \mathrm{~m}$ data using the Power Law.

Power estimates use four configurations of the General Electric GE 1.5-MW series turbines that varied in rotor diameters, cut-in, cut-out and rated speeds.
\end{abstract}

\section{Keywords}

Wind speed; wind energy; Weibull parameters; wind generators; capacity factor.

\section{INTRODUCTION}

Since 2010, Algeria is implementing an ambitious strategy for encouraging and developing renewable energy in its territory. This strategy would gradually replace the use of gas, which currently is the only resource for the country's electricity generation by other energy sources like solar, wind and nuclear energy [1].

National policy for the renewable energies promotion and development is governed by laws and regulations adopted over recent years (law on energy conservation, law on the promotion of renewable energy within a framework of sustainable development, law on electricity with its accompanying decree on the diversification costs) reveal the will of the state to make these energies, the future energies for the country, by encouraging a greater contribution to the national energy mix, and also this policy relies on a whole network of organisations and business companies within of higher education and scientific research and the ministry of energy and mines each one dealing with the development of renewable energies $[1,2]$.

Algeria has a considerable wind resource, whose potential is especially significant in the south with average speeds of 4 to $6 \mathrm{~m} / \mathrm{s}$, is also a valuable resource that can supply domestic needs in remote sites, while the north is found to be less windy with the exception of microclimates in the coastal region of Oran, Bejaia and regions of Tiaret, Biskra and Setif $[1,3]$.

The aim of this paper present a study of the statistical properties of the wind speed and wind potential in Algeria by considering four locations in which the data are recorded by Algerian Meteorological National Office (MNO), and presentation of a simple method for determination of pairing between sites and wind generators.

\section{GEOGRAPHICAL SITUATION OF ALGERIA}

Algeria is located in North Africa bordered in north by the Mediterranean Sea $(1200 \mathrm{~km})$, in the east by Tunisia $(965 \mathrm{~km})$ and Libya $(982 \mathrm{~km})$, in south-east by Niger $(956 \mathrm{~km}$,), in south-west by Mali $(1,376 \mathrm{~km})$ and Mauritania $(463 \mathrm{~km})$, in west by Morocco $(1,559 \mathrm{~km})$ and the Western Sahara $(42 \mathrm{~km})$. Its geographical coordinates are represented by latitude of $28^{\circ}$ $00^{\prime}$ North of the equator and longitude of $3^{\circ} 00^{\prime}$ East of Greenwich [4].

Algeria is the largest country in Africa, in the Arab world, and the Mediterranean and is classified the eleventh in the word in term of its land area. It occupies an area of 2,400,000 km², with an estimated population of 37.1 million as of 2012 and a population density at 16,08 inhabitants $/ \mathrm{km}^{2}$ [5].

\section{WIND DATA}

The geographical locations (latitude, longitude and altitude) for the sites considered in this study are presented in Table 1 and Fig.1. Wind data for 20 meteorological stations were obtained from the Algerian MNO. The data were collected over a period spanned between 1976 and 1988 [6, 7].

At all stations the measurements are obtained at a height of 10 $\mathrm{m}$ above sea level.

Therefore, the wind parameters are extrapolated from the standard height of $10 \mathrm{~m}$ to $30 \mathrm{~m}$ and $50 \mathrm{~m}$ using the power low expression. The Weibull parameters $\mathrm{k}$ and $\mathrm{c}$ are determined and used to estimate the annual mean wind speed and the wind power density for each site.

Table 1 and Fig. 1 shows the geographical location of the study area [8-9].

Table 1. Geographical location for the different sites

\begin{tabular}{|l|c|c|c|c|}
\hline \multicolumn{1}{|c|}{ Sites } & $\begin{array}{c}\text { Longitude } \\
\left({ }^{\circ}\right)\end{array}$ & $\begin{array}{c}\text { Latitude } \\
\left({ }^{\circ}\right)\end{array}$ & $\begin{array}{c}\text { Altitude } \\
(\mathrm{m})\end{array}$ & $\begin{array}{c}\text { Topographic } \\
\text { Situation }\end{array}$ \\
\hline Algiers & $03^{\circ} 15^{\prime} \mathrm{E}$ & $36^{\circ} 43^{\prime} \mathrm{N}$ & 25 & Coastal zone \\
Oran & $00^{\circ} 37^{\prime} \mathrm{W}$ & $35^{\circ} 38^{\prime} \mathrm{N}$ & 99 & \\
\hline Adrar & $00^{\circ} 17^{\prime} \mathrm{W}$ & $27^{\circ} 53^{\prime} \mathrm{N}$ & 264 & Sahara \\
Ghardaia & $03^{\circ} 49^{\prime} \mathrm{E}$ & $32^{\circ} 23^{\prime} \mathrm{N}$ & 450 & \\
\hline
\end{tabular}




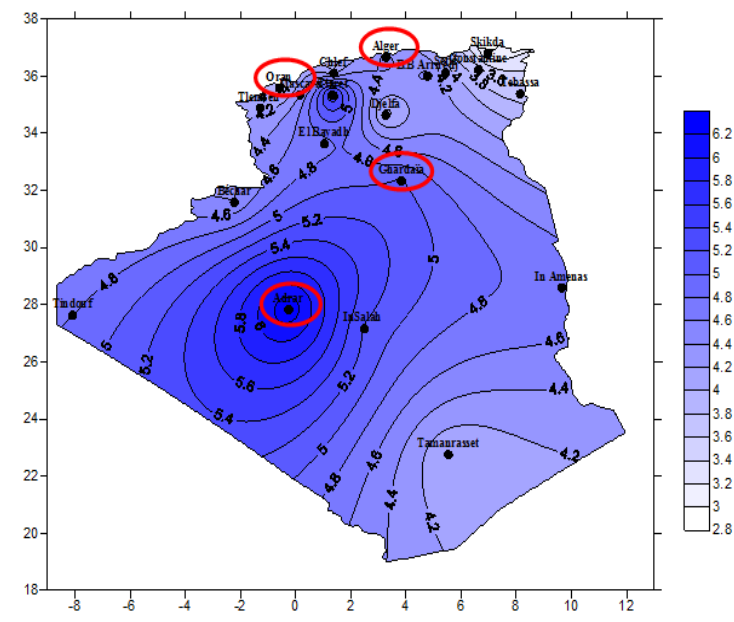

Fig 1: Various wind regimes in Algeria

\section{MATHEMATICAL FORMULATION}

\subsection{Weibull method}

The Weibull distribution function $[10,11]$ is the most frequently used model to describe the distribution of the wind speed. This function gives a good match with the experimental data. It is characterised by two parameters $\mathrm{k}$ and c. this distribution takes the form

$$
f(V)=\left(\frac{k}{c}\right) \cdot\left(\frac{v}{c}\right)^{k-1} \cdot \exp \left[-\left(\frac{v}{c}\right)\right]^{k} \text { for }(\mathrm{k}>0, \mathrm{~V}>0, \mathrm{c}>1)
$$

Where $\mathrm{v}$ is the wind speed, $\mathrm{k}$ is the dimensionless shape parameter, describing the dispersion of the data and c Weibull scale parameter in the unit of wind speed $(\mathrm{m} / \mathrm{s})$.

Moreover, the cumulative density function of the Weibull distribution is defined as $[10,11]$

$$
F(V)=\int_{0}^{\alpha} f(V) \cdot d v=1-e^{-\left(\frac{V}{C}\right)^{k}}
$$

The mean of the distribution $[10,11]$, i. e., the mean wind speed, $\mathrm{V}_{\mathrm{m}}$ is equal to

$$
V_{m}=\int_{0}^{\infty} f(V) \cdot d v=c \cdot \Gamma\left(1+\frac{1}{k}\right)
$$

The most probable wind speed $\left(\mathrm{V}_{\mathrm{E}}\right)$, which represents the most frequent wind speed, is expressed by [12]:

$$
V_{E}=c .\left(1+\frac{2}{k}\right)^{\frac{1}{k}}
$$

Wind speed carrying maximum wind energy can be expressed as follows [12]:

$$
V_{F}=c \cdot\left(1-\frac{1}{k}\right)^{\frac{1}{k}}
$$

$$
\sigma^{2}=\int_{0}^{\infty}(V-\pi V \phi) \cdot f(V) \cdot d v=c^{2} \cdot\left[\Gamma\left(1+\frac{2}{k}\right)-\Gamma^{2}\left(1+\frac{1}{k}\right)\right]
$$

The standard deviation $\sigma$ is then defined as the square root of the variance [14].

$$
\text { Stadard deviation }=\sqrt{\text { Variance }}
$$

The average cubic speed of the wind is given by the following relation [15]

$$
\left\langle V^{3}\right\rangle=\int_{0}^{\infty} V^{3} \cdot P(V) \cdot d v=c^{3} \cdot \Gamma\left(1+\frac{3}{k}\right)
$$

Where $\Gamma$ is the defined gamma function, for any reality $\mathrm{x}$ positive not null, by

$$
\Gamma(x)=\int_{0}^{\infty} \exp (-t) \cdot t^{x-1} \cdot d t \quad \text { with } x \phi 0
$$

\subsection{Vertical extrapolation of wind speed}

The wind data measurements used in this study are used from stations set at a standard height of $10 \mathrm{~m}$. The vertical extrapolation of wind speed is based on the Power law [16-18]

$$
v(z)=v\left(z_{\text {ref }}\right) \cdot\left(\frac{z}{z_{\text {ref }}}\right)^{\alpha}
$$

Where $\mathrm{v}\left(\mathrm{z}_{\mathrm{ref}}\right)$ is the actual wind speed recorded at height $\mathrm{z}_{\mathrm{ref}}$, $\mathrm{v}(\mathrm{z})$ is the wind speed at the required or extrapolated height $\mathrm{z}$ and $\alpha$ is the surface roughness exponent is also a terraindependent parameter.

\subsection{Vertical extrapolation of Weibull parameters:}

The Weibull parameters are also function of height [18-20],

$$
\begin{aligned}
& c(z)=c\left(z_{\text {ref }}\right) \cdot\left(\frac{z}{z_{\text {ref }}}\right)^{n} \\
& k(z)=k\left(z_{\text {ref }}\right) \cdot \frac{1-0.088 \cdot \operatorname{Ln}\left(\frac{z_{\text {ref }}}{10}\right)}{1-0.088 . \operatorname{Ln}\left(\frac{z}{10}\right)}
\end{aligned}
$$

$\mathrm{n}$ is a scalar which can be obtained by the relation

$\mathrm{n}$ is a scalar obtained using the relation

$$
n=\frac{0.37-0.088 . \operatorname{Ln}\left(c\left(z_{\text {ref }}\right)\right)}{1-0.088 . \operatorname{Ln}\left(\frac{z_{\text {ref }}}{10}\right)}
$$

The variance $\sigma^{2}$ of the data is then defined as $[13,14]$ 


\subsection{Estimating wind power}

The kinetic energy of air stream with mass $(\mathrm{m})$ and moving with a velocity $(\mathrm{v})$ is given by [21]

$$
E=\frac{1}{2} m v^{2}[\mathrm{~J}]
$$

The power in moving air is the flow rate of kinetic energy per second. Therefore [21]:

$$
P=\frac{E}{t}=\frac{1 / 2 \cdot m \cdot v^{2}}{t}[\mathrm{w}]
$$

The wind power density $\left(\mathrm{P}_{\mathrm{d}}\right)$ representing the power per unit

$$
P_{d}=\frac{P}{A}=\frac{1}{2} \cdot \rho_{0} \cdot v^{3}\left[\mathrm{w} / \mathrm{m}^{2}\right]
$$

$\rho_{0}$ is the standard air density, $\left(1.225 \mathrm{~kg} / \mathrm{m}^{3}\right)$

$A$ is the area swept by the rotor blades $\left(A=\pi \cdot R^{2}\right),\left[\mathrm{m}^{2}\right]$

$\mathrm{v}$ is the mean wind speed, $\mathrm{m} / \mathrm{s}$

The theoretical maximum power that can be extracted from a wind turbine is limited by Betz's law [23, 24]:

$$
P_{e x t}=\frac{1}{2} \cdot C_{p}(\lambda, \beta) \rho_{0} A \cdot v^{3}
$$

$\mathrm{Cp}(\lambda, \beta)$ the power coefficient, represents the wind turbine aerodynamic efficiency. It depends on the tip speed ratio $\lambda$ and the blade pitch angle $\beta$. The theoretical maximum value for the power coefficient $\mathrm{C}_{\mathrm{p}_{-} \max }$ is 0.59 (the Betz limit).

The air density $\rho_{0}$ varies with temperature and elevation. The monthly mean air density $\left(\mathrm{kg} / \mathrm{m}^{3}\right)$ is calculated using the equation [25]

$$
\rho(T, Z)=\frac{353.049}{T} \cdot \exp \left(-0.034 \cdot \frac{Z}{T}\right)
$$

Where

$\mathrm{Z}$ is the elevation of the site $[\mathrm{m}]$.

$\mathrm{T}$ is the monthly average air temperature $[\mathrm{K}]$

Finally, the corrected wind power density $\left(\mathrm{k} . \mathrm{W} . \mathrm{h} / \mathrm{m}^{2}\right)$, can be computed using:

$$
E_{w d p}=2.586 . \rho \cdot v^{3}
$$

According to [26-29], the wind turbine power curve can be well approximated with the parabolic law:

$$
P(v)=\left\{\begin{array}{llc}
0 & \text { if } & v \pi v_{C} \\
P_{R}\left(\frac{V^{k}-V_{C}^{k}}{V_{R}^{k}-V_{C}^{k}}\right) & \text { if } & v_{C} \leq v \leq v_{R} \\
P_{R} & \text { if } & v_{R} \leq v \leq v_{F} \\
0 & \text { if } & v \phi v_{F}
\end{array}\right.
$$
area can be written [22]:

$v_{R}$ is the rated wind speed, $v_{F}$ is the furling wind speed,

$\mathrm{k}$ is the Weibull shape parameter.

Integrating equation (26), this is [24, 30]:

$$
P_{a v r g}=\int_{0}^{\infty} P(v) \cdot f(v) \cdot d v=\int_{v_{c}}^{v_{F}} P(v) \cdot f(v) \cdot d v
$$

Substituting Eq.26 into Eq. 27 yields

$$
P_{\text {avrg }}=\int_{v_{C}}^{v_{R}} P_{R} \cdot\left(\frac{v^{k}-v_{C}^{k}}{v_{R}^{k}-v_{C}^{k}}\right) \cdot f(v) \cdot d v+\int_{v_{R}}^{v_{F}} P_{R} \cdot f(v) \cdot d v
$$

There are two distinct integration in Eq. 28 which to need be integrated. The integration can be accomplished by making the change in variable.

After calculate [24, 26, 31-33]

$$
P_{\text {avrg }}=P_{R}\left(\frac{\exp \left[-\left(\frac{v_{C}}{c}\right)^{k}\right]-\exp \left[-\left(\frac{v_{R}}{c}\right)^{k}\right]}{\left(\frac{v_{C}}{c}\right)^{k}-\left(\frac{v_{R}}{c}\right)^{k}}-\exp \left[-\left(\frac{v_{F}}{c}\right)^{k}\right]\right)
$$

$P_{\text {avrg }}$ can be expressed as:

$$
P_{\text {avrg }}=P_{R} \cdot C_{F}
$$

Where $\mathrm{C}_{\mathrm{F}}$ is the capacity factor.

\section{RESULTS AND DISCUSSIONS}

The Weibull distribution parameters and characteristics speeds are evaluated, and the numerical results for four Algerians sites are presented in Tables 2 to 4 .

Table 2. Weibull distribution parameters and characteristics speeds for different sites at $10 \mathrm{~m}$ height

\begin{tabular}{|l|c|c|c|c|c|c|c|}
\hline Sites & $\mathbf{k}$ & $\mathbf{c}$ & $\mathbf{V m}$ & $\left\langle\mathbf{V}^{\mathbf{3}}\right\rangle$ & $\boldsymbol{\sigma}$ & $\mathbf{V}_{\mathbf{E}}$ & $\begin{array}{c}\mathbf{V}_{\mathbf{F}} \\
(\mathbf{-})\end{array}$ \\
$(\mathbf{m} / \mathbf{s})$ & $(\mathbf{m} / \mathbf{s})$ & $(\mathbf{m} / \mathbf{s})^{\mathbf{3}}$ & $(-)$ & $(\mathbf{m} / \mathbf{s})$ & \\
\hline Algiers & 2.03 & 5.00 & 4.43 & 163.62 & 3.62 & 3.62 & 7.01 \\
Oran & 1.26 & 4.10 & 3.81 & 201.34 & 5.88 & 5.88 & 8.72 \\
Adrar & 2.15 & 7.20 & 6.38 & 462.23 & 4.85 & 4.85 & 9.78 \\
Ghardaia & 1.65 & 5.60 & 5.01 & 298.97 & 5.32 & 5.32 & 9.06 \\
\hline
\end{tabular}

Table 3. Weibull distribution parameters and characteristics speeds for different sites at $30 \mathrm{~m}$ height

\begin{tabular}{|l|c|c|c|c|c|c|c|}
\hline Sites & $\mathbf{k}$ & $\begin{array}{c}\mathbf{c} \\
(-)\end{array}$ & $\begin{array}{c}\mathbf{V m} \\
(\mathbf{m} / \mathbf{s})\end{array}$ & $\begin{array}{c}\langle\mathbf{m} / \mathbf{s}) \\
(\mathbf{m} / \mathbf{s})^{\mathbf{3}}\end{array}$ & $\begin{array}{c}\boldsymbol{\sigma} \\
(-)\end{array}$ & $\begin{array}{c}\mathbf{V}_{\mathbf{E}} \\
(\mathbf{m} / \mathbf{s})\end{array}$ & $\begin{array}{c}\mathbf{V}_{\mathbf{F}} \\
(\mathbf{m} / \mathbf{s})\end{array}$ \\
\hline Algiers & 2.25 & 6.41 & 5.68 & 313.58 & 4.08 & 08.50 & 4.94 \\
Oran & 1.39 & 5.36 & 4.89 & 358.15 & 6.55 & 10.18 & 2.15 \\
Adrar & 2.38 & 8.92 & 7.91 & 809.00 & 5.31 & 11.53 & 7.09 \\
Ghardaia & 1.82 & 7.10 & 6.31 & 530.89 & 5.91 & 10.67 & 4.58 \\
\hline
\end{tabular}

$P_{R}$ is the rated electrical power; $v_{C}$ is the cut-in wind speed, 
Table 4. Weibull distribution parameters and characteristics speeds for different sites at $50 \mathrm{~m}$ height

\begin{tabular}{|l|c|c|c|c|c|c|c|}
\hline Sites & $\mathbf{k}$ & $\mathbf{c}$ & $\mathbf{V m}$ & $\left\langle\mathbf{V}^{\mathbf{3}}\right\rangle$ & $\boldsymbol{\sigma}$ & $\mathbf{V}_{\mathbf{E}}$ & $\mathbf{V}_{\mathbf{F}}$ \\
$(\mathbf{( - )}$ & $(\mathbf{m} / \mathbf{s})$ & $(\mathbf{m} / \mathbf{s})$ & $(\mathbf{m} / \mathbf{s})^{\mathbf{3}}$ & $(\mathbf{m})$ & \\
\hline Algiers & 2.36 & 7.21 & 6.39 & 429.89 & 4.34 & 09.35 & 5.71 \\
Oran & 1.47 & 6.08 & 5.50 & 466.92 & 6.82 & 10.91 & 2.80 \\
Adrar & 2.50 & 9.86 & 8.75 & 1056.17 & 5.53 & 12.47 & 8.04 \\
Ghardaia & 1.92 & 7.94 & 7.04 & 695.98 & 6.17 & 11.52 & 5.41 \\
\hline
\end{tabular}

The wind speed data for the four selected station are presented in Fig.3. As shown, Adrar has the highest wind speed in the area, but present significant fluctuations between months and seasons. Ghardaia has also high wind speed with limited fluctuations over the year. Besides, Oran presents rather lower wind speed, while Algiers is the last windy site.

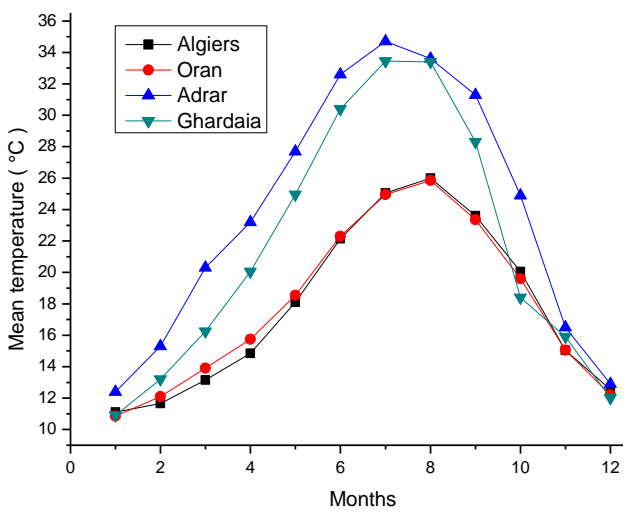

Fig 2: Mean monthly temperatures for the selected sites.

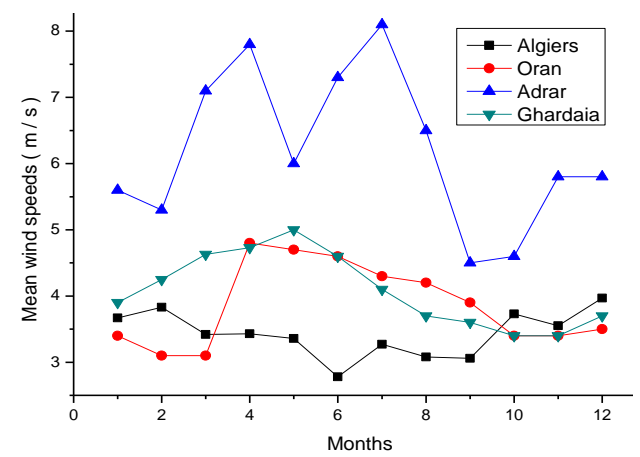

Fig 3: Mean monthly wind speeds for selected sites

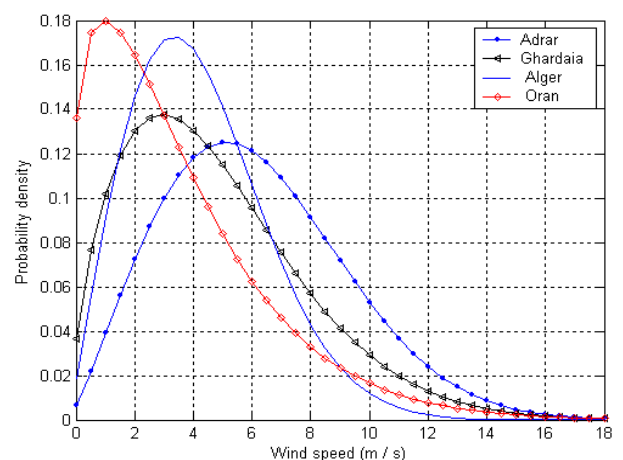

Fig 4: Weibull probability density function at $10 \mathrm{~m}$ height

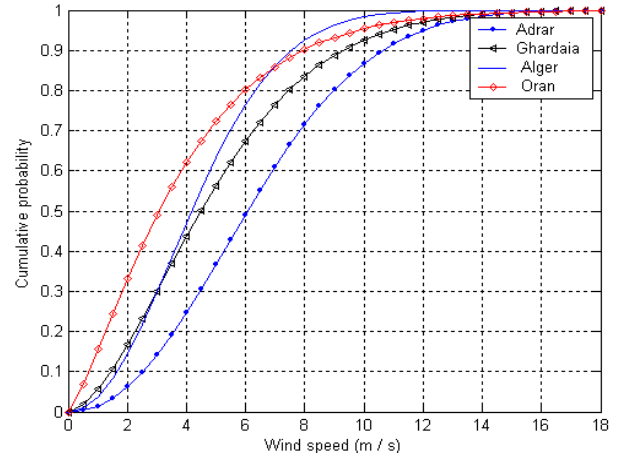

Fig 5: Weibull cumulative distribution function at $10 \mathrm{~m}$ height

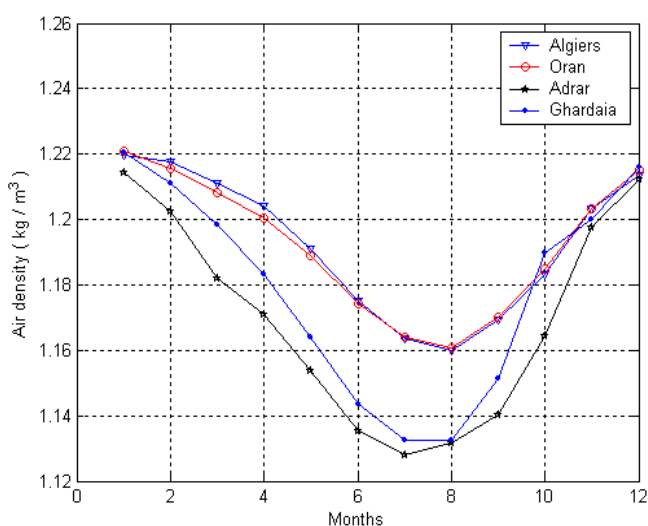

Fig 6: Monthly air density

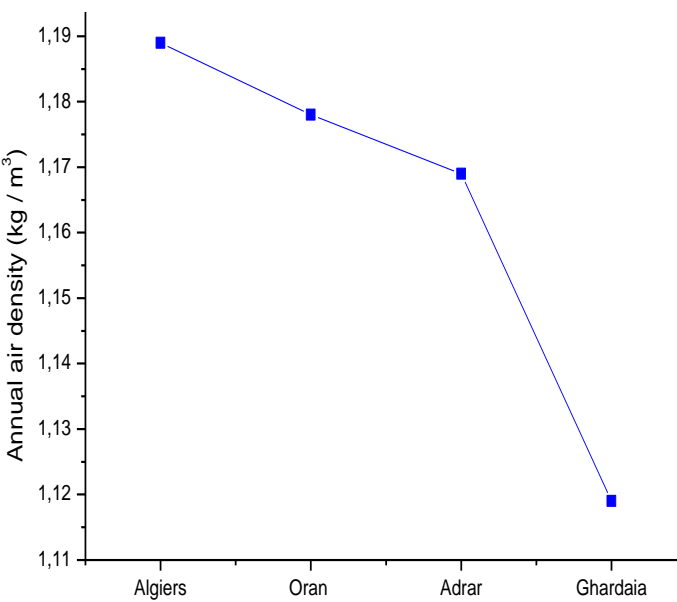

Fig 7: Annual air density

- It is noticed that the great decreases of the air density is recorded in the sites of Adrar and Ghardaia, these sites are respectively characterized by the very elevated heights above sea level ( $264 \mathrm{~m}$ and $450 \mathrm{~m})$, while the weak variation is noticed in the very low heights sites, Algiers (25 m) and Oran sites (99 m).

- The density of air decreases with the increase in site elevation and temperature as illustrated in Fig.6 and 7.

- The highest decreases of the air density are found during the summer season in all stations and the lowest values are found during the winter season. 
- Annual values of corrected wind power are smallest that the uncorrected wind power (see Fig.8).

We notice that the shape and scale parameters increase as the height increases. At $10 \mathrm{~m}$ height, the shape parameter $\mathrm{k}$ varied between 1.26 (Oran) and 2.15 (Adrar) while the scale parameter c varied between $4.10 \mathrm{~m} / \mathrm{s}$ (Algiers) and $7.20 \mathrm{~m} / \mathrm{s}$ (Adrar), and for $50 \mathrm{~m}$ height, the shape parameter varied between 1.47 (Oran) and 2.50 (Adrar) while the scale parameter c varied between $6.08 \mathrm{~m} / \mathrm{s}$ (Algiers) and $9.86 \mathrm{~m} / \mathrm{s}$ (Adrar).

The highest values of annual mean wind power density are found in Adrar $\left(\mathrm{P}_{10}=283.12 \mathrm{~W} / \mathrm{m}^{2}\right)$, where the lowest values of annual mean wind power density are found in Algiers $\left(\mathrm{P}_{10}=100.22 \mathrm{~W} / \mathrm{m}^{2}\right)$.

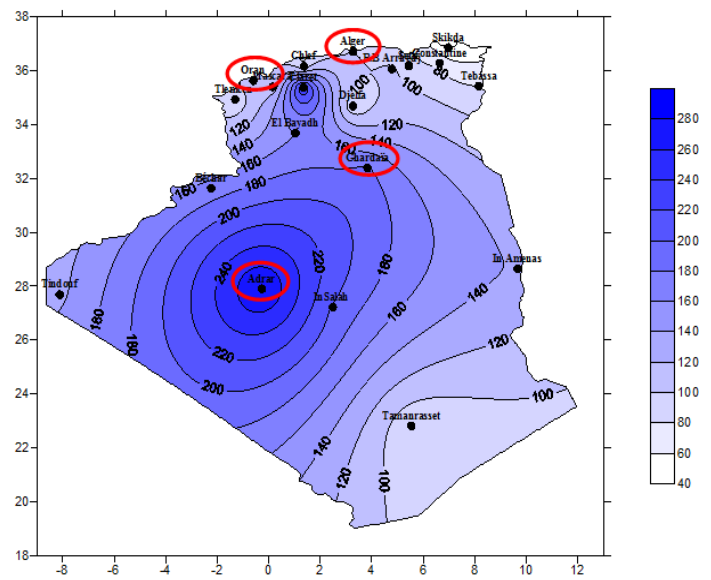

Fig 8: distribution of wind power density over Algeria at $10 \mathrm{~m}$ height

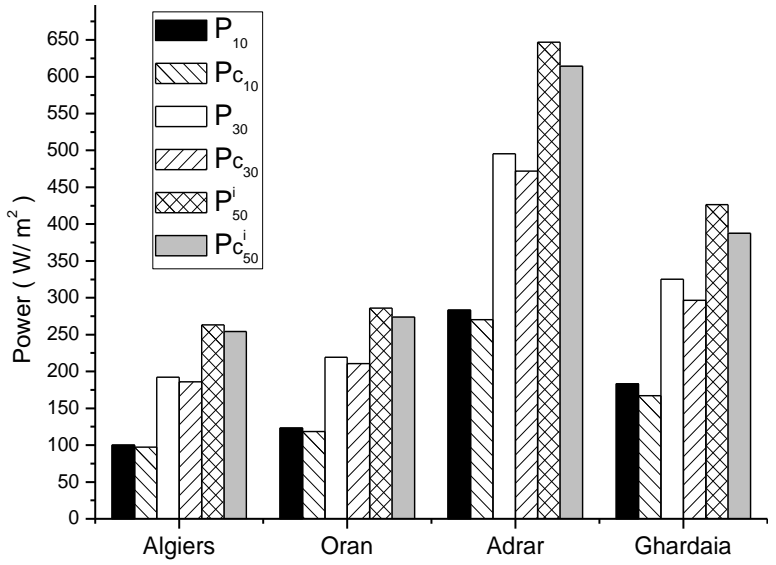

Fig 9: Computations of the annual corrected and uncorrected wind power by Weibull distribution for different heights.

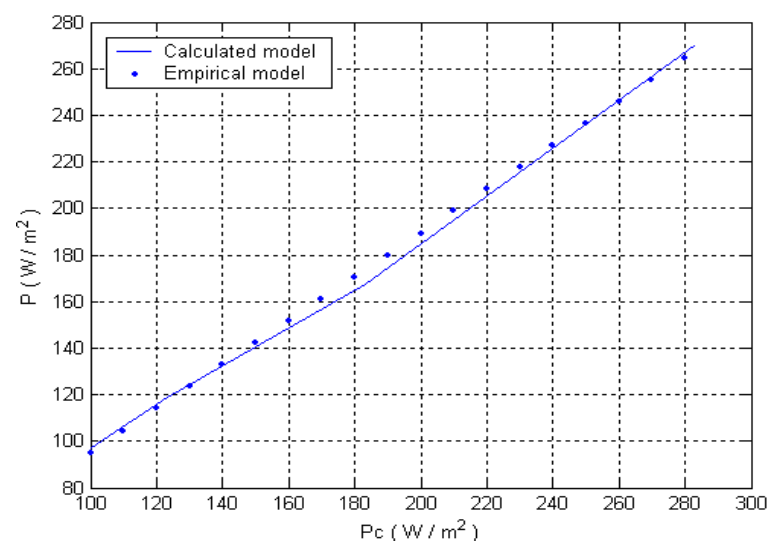

Fig 10: Correlation between monthly values of corrected $P c$ and uncorrected wind power $P$ of the selected stations

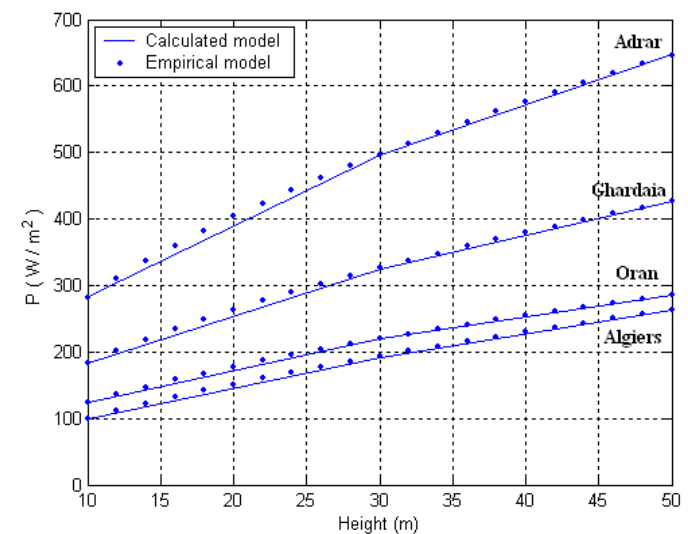

Fig 11: Correlation between monthly values of uncorrected wind power $P$ and height $Z$ of the selected stations.

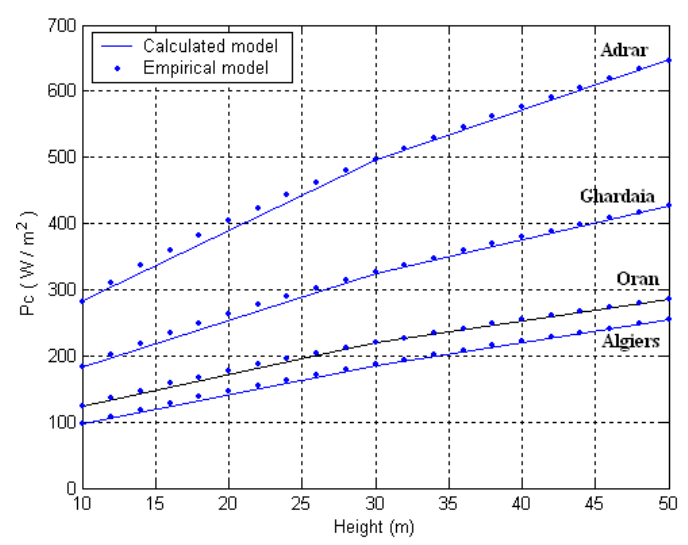

Fig 12: Correlation between monthly values of corrected wind power $P c$ and height $Z$ of the selected stations 


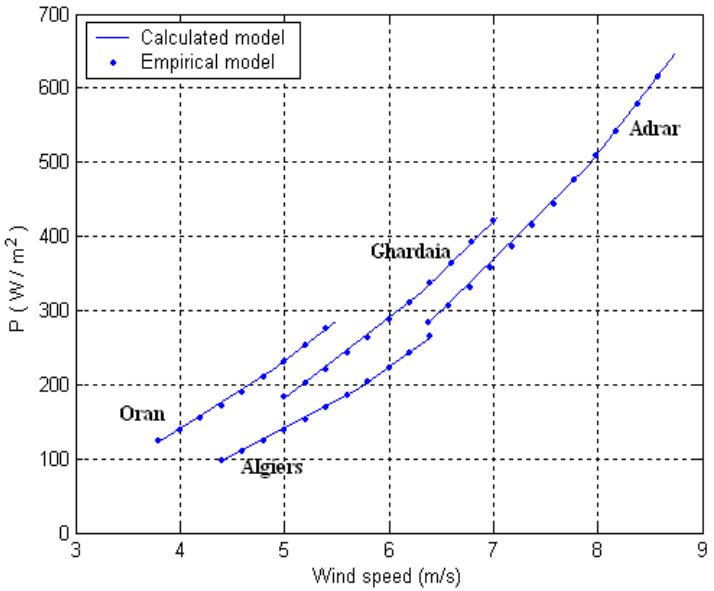

Fig 13: Correlation between monthly values of uncorrected wind power $P$ and wind speed $V$ of the selected stations.

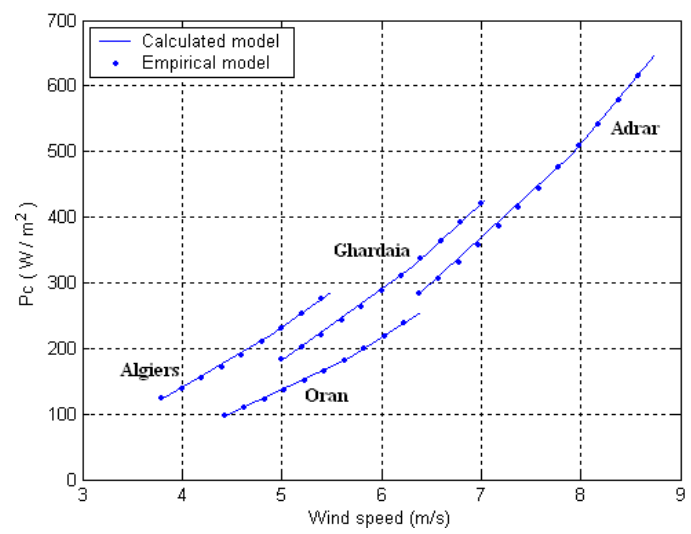

Fig 14: Correlation between monthly values of corrected wind power Pc and wind speed $\mathrm{V}$ of the selected stations.

A linear relation was observed between mean monthly power densities and measured mean monthly wind speeds. The correlation equation is $(\mathrm{CC} \approx 0.997)$ :

$$
P=0.881+0.942 P_{C}
$$

For the selected stations, a Correlation between monthly uncorrected wind power $\mathrm{P}$ and corrected wind power $\mathrm{Pc}$ with height $\mathrm{Z}$ has been investigated and illustrated in Fig. 11 and Fig.12. A strong correlation has been found between P, Pc and $\mathrm{Z}$, where we obtain a correlation coefficient of $\mathrm{CC}=0.99$.

The recommended correlation equations are respectively given by:

$$
\begin{aligned}
& P=a . Z^{b} \\
& P_{C}=a \cdot Z^{b}
\end{aligned}
$$

Where $\mathrm{a}$ and $\mathrm{b}$ are constants, being dependent on the characteristics on the selected site, are provided respectively in Table 5 and 6.

The variation of monthly mean uncorrected power $\mathrm{P}$ and monthly mean corrected power PC with measured monthly mean wind speed are presented in Fig.13 and Fig.14. As can be seen, there are a strong correlation, $\mathrm{CC}>0.99$, between the monthly mean powers and the measured monthly mean wind speeds.

The recommended correlation equations are respectively given by:

$$
\begin{aligned}
& P=a . V^{b} \\
& P_{C}=a . V^{b}
\end{aligned}
$$

Where $\mathrm{a}$ and $\mathrm{b}$ are constants, being dependent on the characteristics on the selected site, are provided respectively in Table 7 and 8.

Table 5. Parameters $a, b$ and $R^{2}$ of the empirical model of energy and for the selected stations.

\begin{tabular}{|l|c|c|c|}
\hline \multicolumn{1}{|c|}{ Sites } & a & b & $\mathbf{R}^{\mathbf{2}}$ \\
\hline Algiers & 24.89588 & 0.60249 & 0.99991 \\
Oran & 37.09080 & 0.52224 & 0.99999 \\
Adrar & 86.37732 & 0.51441 & 0.99996 \\
Ghardaïa & 54.50057 & 0.52563 & 0.99999 \\
\hline
\end{tabular}

Table 6. Parameters $a, b$ and $R^{2}$ of the empirical model of energy and for the selected stations.

\begin{tabular}{|l|c|c|c|}
\hline \multicolumn{1}{|c|}{ Sites } & a & b & $\mathbf{R}^{\mathbf{2}}$ \\
\hline Algiers & 4.29842 & 0.59983 & 0.99989 \\
Oran & 7.09080 & 0.52224 & 0.99999 \\
Adrar & 86.37730 & 0.51441 & 0.99996 \\
Ghardaïa & 54.50057 & 0.52563 & 0.99999 \\
\hline
\end{tabular}

Table 7. Parameters $a, b$ and $R^{2}$ of the empirical model of energy and for the selected stations.

\begin{tabular}{|l|c|c|c|}
\hline \multicolumn{1}{|c|}{ Sites } & a & b & $\mathbf{R}^{\mathbf{2}}$ \\
\hline Algiers & 1.96054 & 2.64154 & 0.99998 \\
Oran & 5.80200 & 2.28701 & 0.99996 \\
Adrar & 2.20546 & 2.61894 & 0.99998 \\
Ghardaïa & 3.35429 & 2.48265 & 1.00000 \\
\hline
\end{tabular}

Table 8. Parameters $a, b$ and $R^{2}$ of the empirical model of energy and for the selected stations.

\begin{tabular}{|l|c|c|c|}
\hline \multicolumn{1}{|c|}{ Sites } & a & b & $\mathbf{R}^{\mathbf{2}}$ \\
\hline Algiers & 1.93486 & 2.62994 & 0.99997 \\
Oran & 5.80200 & 2.28701 & 0.99996 \\
Adrar & 2.20546 & 2.61894 & 0.99998 \\
Ghardaïa & 3.35429 & 2.48265 & 1.00000 \\
\hline
\end{tabular}


Table 9 gives the technical specifications of four configurations of the General Electric (GE) 1.5-MW series wind turbine used in this study [34].

Table 9 . Characteristics of 1.5 MW Series Wind Turbine used in this study.

\begin{tabular}{|l|l|c|c|c|c|}
\hline $\mathbf{N}^{\circ}$ & Manufacturer & $\begin{array}{c}\mathbf{P} \\
\mathbf{R}\end{array}$ & $\begin{array}{c}\mathbf{v} \\
(\mathbf{C} / \mathbf{w})\end{array}$ & $\begin{array}{c}\mathbf{v} \\
(\mathbf{R} / \mathbf{s})\end{array}$ & $\begin{array}{c}\mathbf{v} \\
(\mathbf{m} / \mathbf{s})\end{array}$ \\
\hline 01 & $1.5 \mathrm{se}$ & 1.5 & 4 & 13 & 25 \\
02 & $1.5 \mathrm{sl}$ & 1.5 & 3.5 & 14 & 20 \\
03 & $1.5 \mathrm{sle}$ & 1.5 & 3.5 & 14 & 25 \\
04 & $1.5 \mathrm{xle}$ & 1.5 & 3.5 & 12.5 & 20 \\
\hline
\end{tabular}

We calculate the capacity factor $\mathrm{C}_{\mathrm{F}}$ for each turbine-site, and the results are presented in tables 10,11 and 12 at the height of 10,30 and $50 \mathrm{~m}$, respectively.

The capacity factor of the system can be a useful indication for the effective matching of wind turbine and regime. For turbines with the same rotor size, rated power and conversion efficiency, the capacity factor is influenced by the wind generators (cut-in speed, rated speed and cut-out speed) and the site characteristics (shape and scale parameters).

Table 10. Capacity factors $C_{F}^{10}(\%)$ calculated for 4 turbines configurations and for different sites at $10 \mathrm{~m}$ height

\begin{tabular}{|c|l|c|c|c|c|}
\hline Site $^{\circ}$ & Turbin $\mathbf{N}^{\circ}$ & $\mathbf{1}$ & $\mathbf{2}$ & $\mathbf{3}$ & $\mathbf{4}$ \\
\hline 1 & Algiers & 08.36 & 08.10 & 08.10 & $\mathbf{1 0 . 3 4}$ \\
2 & Oran & 11.04 & 11.13 & 11.13 & $\mathbf{1 3 . 0 2}$ \\
3 & Adrar & 22.12 & 20.01 & 20.01 & $\mathbf{2 5 . 1 8}$ \\
4 & Ghardaia & 15.85 & 15.22 & 15.22 & $\mathbf{1 8 . 4 1}$ \\
\hline
\end{tabular}

Table 11. Capacity factors $C_{F}^{30}(\%)$ calculated for 4 turbines configurations and for different sites at $30 \mathrm{~m}$ height

\begin{tabular}{|c|l|c|c|c|c|}
\hline Site $\mathbf{N}^{\circ}$ & TurbinN $^{\circ}$ & $\mathbf{1}$ & $\mathbf{2}$ & $\mathbf{3}$ & $\mathbf{4}$ \\
\hline 1 & Algiers & 15.34 & 13.91 & 13.91 & $\mathbf{1 8 . 0 0}$ \\
2 & Oran & 17.44 & 17.03 & 17.04 & $\mathbf{1 9 . 9 2}$ \\
3 & Adrar & 33.70 & 29.97 & 29.97 & $\mathbf{3 7 . 2 1}$ \\
4 & Ghardaia & 24.63 & 22.96 & 22.96 & $\mathbf{2 7 . 6 6}$ \\
\hline
\end{tabular}

Table 12. Capacity factors $C_{F}^{50}(\%)$ calculated for 4 turbines configurations and for different sites at $50 \mathrm{~m}$ height

\begin{tabular}{|c|l|c|c|c|c|}
\hline Site $\mathbf{N}^{\circ}$ & Turbin $\mathbf{N}^{\circ}$ & $\mathbf{1}$ & $\mathbf{2}$ & $\mathbf{3}$ & $\mathbf{4}$ \\
\hline 1 & Algiers & 20.20 & 17.92 & 17.92 & $\mathbf{2 3 . 2 1}$ \\
2 & Oran & 21.29 & 20.52 & 20.53 & $\mathbf{2 3 . 9 9}$ \\
3 & Adrar & 40.43 & 35.97 & 35.97 & $\mathbf{4 4 . 0 4}$ \\
4 & Ghardaia & 29.83 & 27.55 & 27.55 & $\mathbf{3 3 . 0 3}$ \\
\hline
\end{tabular}

We notice that:

- The capacity factor depends on five parameters; shape and scale Weibull parameters, cut-in, cut-out and rated speeds.
- The best capacity factor for each site is shown in boldface in tables 10,11 and 12 .

- The best site for each turbine is $\mathrm{N}^{\circ} 3$ Adrar: $\left(10.34 \leq \mathrm{C}_{\mathrm{F}}^{10}\right.$ $\leq 25.18$ at $10 \mathrm{~m}$ height, $18.00 \leq \mathrm{C}_{\mathrm{F}}^{30} \leq 37.21$ at $30 \mathrm{~m}$ height and for $50 \mathrm{~m}$ height $23.21 \leq \mathrm{C}_{\mathrm{F}}^{50} \leq 44.04$ ).

- The perfects turbines for all sites are respectively $\mathrm{N}^{\circ} 4$ and $\mathrm{N}^{\circ} 1$.

- The capacity factor increases as the hub height increases.

- At $10 \mathrm{~m}$ height the capacity factors of the selected wind turbines are in the range $08-25$. Since the capacity factor at $50 \mathrm{~m}$ height is expected to be in the range 18-44.

\section{CONCLUSIONS}

In this paper, the first part of the study presents an evolution of the wind resource of in four Algerian sites (Algiers, Oran, Adrar and Ghardaïa), the annual average wind velocity and power density at the standard height (10m above the ground) are calculated using the Weibull distribution function. The annual average wind speed for the considered sites ranges from 3.81 to $6.38 \mathrm{~m} / \mathrm{s}$ and the mean wind power density vary between 70.88 and $283.12 \mathrm{w} / \mathrm{m}^{2}$ at standard height of $10 \mathrm{~m}$.

In the second part we calculate the capacity factor and the average power output for 04 commercial wind turbines used in this study. At $10 \mathrm{~m}$ height the capacity factors of the selected wind turbines are in the range 08-25. Since the capacity factor at $50 \mathrm{~m}$ height is expected to be in the range $18-44$.

Wind energy exploitation in Adrar is favourable for applications of low power, as water pumping systems and production of electricity using small wind turbines, and even for the installations of great power and wind farms.

\section{REFERENCES}

[1] Guidelines to renewable energies. Ministry of energy and mines. Algeria .Edition 2007.

[2] Khelif, A. Expérience, potentiel et marché photovoltaïque

algérien.www.worldenergy.org/documents/congresspapers/94. pdf

[3] Ministère de l'aménagement du territoire et de l'environnement; Communication nationale initiale de l'Algérie à la conversion cadre des nations unies sur les changements climatiques. Mars 2001.

[4] www.worldtravelguide.net/Algeria/weather-climategeography.

[5] National Office of the Statistics-Algeria. www.ons.dz

[6] Hammouche, R. 1990 Atlas vent de l'Algérie/ONM. Algiers: Office des publications Universitaires (OPU).

[7] M.N. Kasbadji, " Wind energy potential of Algeria ". Renewable energy 21. 2000. 553-562.

[8] Capderou, M. 1989 Atlas solaire de l'Algérie, Tome 2, Aspect énergétique.

[9] Maouedj, R, Bouchouicha, K, and Benyoucef, B. 2011. Evaluation of wind energy potential in the Saharan sites of Alegria , $10^{\text {ème }}$ Conférence sur l'Environnement et le Génie Electrique. Rome, Italie. 
[10] ASK. Darwish, AAM. Sayigh, "Wind energy potential in Iraq". Solar and Wind Technology 1988; 5 (3):215-22.

[11] TJ. Chang, YT. Wu, HY. Hsu, CR. Chu, CM. Liao. "Assessment of wind characteristics and wind turbine characteristics in Taiwan". Renew energy 2003; 28:85171 .

[12] M. Elamouri, and F. Ben Amar, "Wind energy potential in Tunisia". Renewable energy 33. 2008. 758-768.

[13] M. Jamil, S. Parsa, M. Majidi, "Wind power statistics and evaluation of wind energy density". Renew Energy 1995; 6: 623-8.

[14] Johnson, G. L. 2006. Wind Energy Systems,

[15] Keoppl GW. 1982. Putnam's power from the wind. New York: Van Nostrand Reinhold.

[16] Troen, I., Lundtang, E. 1988. European wind atlas. Roskilde, Denmark: Riso National Laboratory.

[17] M. Amr, H. Petersen, SM. Habali. "Assessment of wind farm economics in relation to site wind resources applied to sites in Jordan". Solar Energy 1990; 45: 167-75.

[18] Justis, C.G. / Traduit et adapté par. Plazy J. L. 1982. Vent et performances des éoliennes, édition S.C.M, Paris.

[19] DeMoor, G. 1983. Les théories de la turbulence dans la couche-limite atmosphérique. Ministère des transports. Direction de la meteorology.

[20] Hladik, J. 1984. Energétique éolienne. Chauffage éolien. Production d'électricité. Pompage, Masson.

[21] S.W. Mohod, M.V. Aware. " Laboratory development of wind turbine simulator using variable speed induction motor ". International Journal of Engineering, Science and Technology Vol. 3, $\mathrm{N}^{\mathrm{o}} .5,2011$, pp. 73-82.

[22] H.S. Bagiorgas, M.N. Assimakopoulos, D. Theoharopoulos, D. Matthopoulos and G.K. Mihalakakou. "Electricity generation using wind energy conversion system in the area of Western Greece". Energy conversion and management 48. 2007.16401655.
[23] T. Petru, T. Thiringer. "Modelling of wind turbines for power system studies", IEEE Trans. Energy Convers. 17 (November (4)) (2002) 1132-1139.

[24] Muljadi, E., Pierce, K., Migliore, P., 1998. Control strategy for variable speed stall regulated wind turbines, in: Proceedings of the American Control Conference, Philadelphia.

[25] Sathyajith, M. 2006. Wind Energy Fundamentals, Resource Analysis and Economics, Springer.

[26] WR. Powell. " An analytical expression for the average output power of a wind machine". Solar Energy 1981; 26: 77-80.

[27] R. Chedid, H. Akiki, S. Rahman. "A decision support technique for the design of hybrid solar-wind power systems". IEEE Trans Energy Convers 1998; 13(1):7683 .

[28] MJM. Stevens, PT. Smulders. "The estimation of the parameters of the Weibull wind speed distribution for wind energy utilization purposes". Wind Eng 1979; $3: 132-45$.

[29] R. Pallabazzer. " Previsional estimation of the energy output of wind generators". Renew Energy 2004;29: 413-20

[30] Hu Ssu-yuan and Jung-ho Cheng. "Performance evaluation of paring between sites and wind turbine". Renewable energy 32. 2007. 1934-1947.

[31] H. Nfaoui, J. Bahraui. "Wind energy potential in Morocco". Renewable Energy 1991; 1:1-8.

[32] A. El-Mallah, AM. Soltan. "A nomogram for estimating capacity factors of wind turbines using site and machine characteristics". Sol Wind Technol 1989; 6: 633-5.

[33] JL. Torres, E. Prieto, A. Garcia, M. De Blas, F. Ramirez, A. De Francisco. "Effects of the model selected for the power curve on the site effectiveness and the capacity factor of a pitch regulated wind turbine". Solar Energy 2003; 74: 93-102.

[34] GE Energy. 2005. 1.5 MW Series Wind Turbines. Product brochure. Available at http://www.gepower.com/prod_serv/products/wind_turbi nes/en/downloads/ge_15_brochure.pdf 